\title{
Hydrocarbon-Butane an Alternative Refrigerant For Cfcs And Hefes
}

\author{
* I.C. Oshuoha, E.B. Bassey, E.J. Ojo \\ Department of Mechanical Engineering, University of Agriculture, Makurdi, Benue State. \\ Department of Physics, Federal College of Education Obudu, Cross-Rivers State. \\ Department of Mechanical Engineering, University of Agriculture, Makurdi, Benue State.
}

\begin{abstract}
Refrigeration can be described as a remarkable achievement of science. The use of some refrigerants such as CFCs and HCFCs are harmful to the environment and depletes the ozone layer which protects the Earth from radiation. And facilitates global warming. The investigation of hydrocarbons - butane as refrigerant that is environmentally friendly, with zero ozone depletion potential (ODP), global warming potential (GWP) less than three. This will also help provide an alternative use to the hydrocarbons - butane being flared from refineries and crude oil drilling sites.
\end{abstract}

Keywords: - harmful, environment, depletes, flared, global warming.

\section{INTRODUCTION}

The concept of refrigeration is very important and can be described as one of the greatest achievements of scientists in the twentieth century. It has a variety of applications ranging from refrigeration of water, drinks to air conditioning. Mechanical refrigeration has been around since the mid-nineteenth century. The first practical machine was built by Jacob Perkins 1834 (Thevenot, 1979). It was based on using ether as a refrigerant in a vapour compression circuit. Carbon (iv) oxide $\left(\mathrm{CO}_{2}\right)$ was also used as a refrigerant in 1866 and ammonia $\left(\mathrm{NH}_{3}\right)$ in 1873. Other chemicals used as vapour compression refrigerants include chymgene (petrol, ether and naphtha), sulphur (iv) oxide (R-764) and methyl ether. Their applications were limited to industrial processes. Most food preservation was accomplished by using blocks of ice collected during and stored or manufactured through an industrial process (McQuay, 2002).

By the beginning of the twentieth century, refrigeration systems were being used to provide air conditioning in major building projects. The Milam building in San Antonio, Texas was the first high-rise buildings to be completely air conditioned (Pauken, 1999).

In 1926, Thomas Midgely developed the first CFC (chlorofluorocarbons), R-12. CFCs were nonflammable, non toxic (when compare to sulphur (iv) oxide) and efficient. Commercial production began in 1931 and quickly found a home in refrigeration. Wills Carrier developed the first centrifugal chiller for commercial use and the era of refrigeration and air conditioning began.

Unfortunately. The CFCs and HCFCs are so stable that when discharged to atmosphere the molecules diffuse to the stratosphere before being ultimately decomposed by ultraviolet radiation. It has now been found that the liberated chlorine atoms attack the ozone layer which protects the Earth from that radiation - and moreover by a chain reaction wherein every chlorine atom breaks up about 105 ozone molecules (Rogers and Mayhew, 1992).

By the mid 1970s concerns began to surface about the thinning of the ozone layer and whether CFCs may be in part responsible. This led to the ratification of the Montreal protocol in 1987 that required the phase out of CFCs HCFCs. (McQuay 2002). In the 1990s global warming arose as the threat to all well being of the planet. Hence urgent steps are needed to stem-down this tide.

\section{MATERIALS AND METHOD}

Materials used for this research include mild steel plates guage-22, aluminum sheet, angle iron-2cm, fibre-cork board, copper tubing $0.9 \mathrm{~mm}$ to $1.0 \mathrm{~mm}$, butane R-600, as refrigerant, ${ }^{1} / 2 \mathrm{Hp}$ rating compressor. These materials can be sourced and bought locally from the market.

The cabinet unit being the main structure of the freeze carries the other units, therefore it must be constructed to give rigidity and support to other members. First, the angle iron is used to frame the structure length $70 \mathrm{~cm}$, height $60 \mathrm{~cm}$, and weight $50 \mathrm{~cm}$. Then the mild steel plates are used as the main outer plate and the base plate. A recess of dimension $(50 \times 25 \times 25) \mathrm{cm}$, the seating for compressor.

The fibre-cork board is then placed inside the main outter plate, before the aluminum plate which is used as the inner plate which is folded round with the copper/capillary tubings-space at $7.00 \mathrm{~cm}$ from one another. The inner plate of aluminum and folded copper tubing is attached to the insulator with the use of an 
appropriate adhesive. The door unit is the most stressed part of the structure being subjected to mechanical opening and closing stress cycle all the time. As a result, the unit is usually the first to show signs of mechanical fatigue/failure before the other structural members. The vulnerability to antique stresses is a function of the height of the unit amongst others.

Therefore, the design of the door unit is directed at reducing the height of the unit as much as possible and its rigidity. The dimension length $70 \mathrm{~cm}$, width $50 \mathrm{~cm}$, and thickness $2 \mathrm{~cm}$. Double walled with fibre-cork in between the outside mild-steel plate and aluminum plate thickness of insulator cork $-2 \mathrm{~cm}$

The copper tubing is connected to the compressor and other refrigeration cycle components - evaporator, condenser and expansion value. A simple vapour compression refrigeration system cycle with superheated vapour before compression.

\section{REFRIGERANT}

A refrigerant can be described as any substance having thermodynamic properties, capable of changing state from liquid to gaseous state and vice-versa with the resultant refrigerating effect and heat rejection at different stages of the process.

\begin{tabular}{|c|c|c|c|c|c|c|c|}
\hline $\begin{array}{l}\text { Refrigeatant } \\
\text { Number }^{\mathrm{a}}\end{array}$ & Chemical Name ${ }^{a}$ & $\begin{array}{l}\text { Chemical } \\
\text { Formula }^{\mathrm{a}}\end{array}$ & $\begin{array}{l}\text { Molecular } \\
\text { Mass }^{\mathrm{a}}\end{array}$ & $\begin{array}{l}\text { Safety } \\
\text { Group }^{a}\end{array}$ & $\begin{array}{l}\text { Atomspheric } \\
\text { Lifetime }^{\mathrm{b}} \text { (yrs) }\end{array}$ & ODP $^{c}$ & GWP \\
\hline 11 & Trichlorofluoromethane & $\mathrm{CCl}_{3} \mathrm{~F}$ & 137.4 & A1 & 50 & 1 & 3800 \\
\hline 12 & Dichlorofluoromethane & $\mathrm{CCl}_{2} \mathrm{~F}_{2}$ & 120.9 & A1 & 102 & 1 & 8100 \\
\hline 22 & Chlorodifluoromethane & $\mathrm{CHClF}_{2}$ & 86.5 & A1 & 12.1 & .055 & 1500 \\
\hline 32 & Difluoromethane & $\mathrm{CH}_{2} \mathrm{~F}_{2}$ & 52 & $\mathrm{~A} 2$ & 5.6 & 0 & 650 \\
\hline 123 & $\begin{array}{l}\text { 2,2-dichloro-1,1,1- } \\
\text { trifluoroethane }\end{array}$ & $\mathrm{CHCl}_{2} \mathrm{CF}_{3}$ & 153 & B1 & 1.4 & .02 & 90 \\
\hline 125 & Pentafluoroethane & $\mathrm{CHF}_{2} \mathrm{CF}_{3}$ & 120 & A1 & 32.6 & 0 & 2800 \\
\hline 134a & $\begin{array}{l}1,1,1,2- \\
\text { tetrafluoroethane }\end{array}$ & $\mathrm{CF}_{3} \mathrm{CH}_{2} \mathrm{~F}$ & 102 & A1 & 14.6 & 0 & 1300 \\
\hline 245fa & $\begin{array}{l}1,1,2,2,3- \\
\text { pentafluoropropane }\end{array}$ & $\mathrm{CHF}_{2} \mathrm{CH}_{2} \mathrm{CF}_{3}$ & 134.05 & B1 & 8.8 & 0 & 820 \\
\hline 290 & Propane & $\mathrm{CH}_{3} \mathrm{CH}_{2} \mathrm{CH}_{3}$ & 44 & A3 & $<1^{\mathrm{n}}$ & 0 & 0 \\
\hline 600 & Butane & $\mathrm{CH}_{3} \mathrm{CH}_{2} \mathrm{CH}_{3}$ & 58.1 & A3 & $<1^{\mathrm{n}}$ & 0 & 0 \\
\hline 717 & Ammonia & $\mathrm{NH}_{3}$ & 17 & $\mathrm{~B} 2$ & N/A & 0 & 0 \\
\hline
\end{tabular}

Table 1 - Refrigerant properties

Source:

${ }^{a}$ ASHRAE, 1997.ANSI/ASHRAE Standard 34-1997. Designation and Safety Classification of Refrigerants Atlanta, Ga: ASHRAE

${ }^{\mathrm{b}} 1995$ IPCC Report HFCs Table 2.9: CFCs and HCFCs Table 2.2 (Houghton et al.,1996)

'Ozone Secretariat UNEP (1996)

\section{BASIC COMPONENTS OF VAPOUR COMPRESSION CYCLE}

The basic components of the vapour compression cycle include : evapourator compressor condenser and expansion device.

Evaporator this is a heat exchanger that removes the build-up heat from the chilled water/food substance, lowering the water/food substance temperature in the process. The heat is used to boil the refrigerant, changing it from liquid to gas (vapour).

Compressor the compressor assembly is made up of a prime mover (typically an electric motor) and a compressor. The compressor raises the pressure and temperature of the refrigerant gas.

Condenser similar to the evaporator, the condenser is a heat exchanger. In this case, it removes heat from the refrigerant causing it to condense from gas to liquid. The heat raises the water temperature. The condenser water then carries the heat to the cooling tower where the heat is rejected to the atmosphere.

Expansion Device after the refrigerant condenses to a liquid, it passes

through a pressure-reducing device. This can be as simple as an orifice plate or as complicated as an electronic modulating thermal expansion valve. Pressure-Enthalpy Diagram

Also the Pressure-Enthalpy $(\mathrm{P}-\mathrm{H})$ diagram is used to analyse the refrigeration cycle. It is an indispensable tool for refrigeration as the various processes are clearly identified. Figure 1 shows the Pressure-Enthalpy $(\mathrm{P}-\mathrm{H})$ diagram for the same refrigeration circuit shown in Figure 1. The process for each of the components is indicated. The evaporator process is from point 1 to point 2 . As the refrigerant changes from a liquid to gas, the pressure (and temperature) stays constant. The heat is being absorbed as a phase change (latent energy). The refrigeration effect is the change in enthalpy from 1 to 2 , simply expressed as Btu/lb. of refrigerant circulated. 
The line from 2 to 3 represents the compression process. The work is the change in enthalpy from point 2 to point 3 times the flow of refrigerant. Simply, Btu/lb. times the $\mathrm{lb} . / \mathrm{min}$ equals compressor power.

Compressors end up with the work of compression as heat in the refrigerant. The vertical aspect of the curve shows the rise in refrigerant pressure (and temperature) from 2 to 3.

The next process takes place in the condenser. The first section (outside the refrigerant dome) is the desuperheating process. Once the refrigerant is saturated, condensation occurs and the refrigerant changes from a gas to a liquid. Like the evaporator, the line is horizontal indicating constant pressure (or temperature). The final process is the expansion device. This appears as a vertical line from point 4 to point 1 ,indicating the pressure (and temperature) drop that occurs as the refrigerant passes through the

Thermal Expansion (TX) valve (McQuay, 2002)

Figure 1 Refrigeration Circuit, P-H Diagram

Required Parameters

Total cooling load,

Refrigerating effect,

Mass flow rate of refrigerant,

Compressor power,

Coefficient of performance of the freeze, and Volume flow rate of air/heat rejection at the condenser.

Derivative and Calculations

Product Data

Product = meat and fish products

Relative humidity (R.H) $=85 \%$

Average density $=1,060 \mathrm{~kg} / \mathrm{m}^{3}$

Storage temperature $=-1.1$ to $0.5^{\circ} \mathrm{C}$

Cp above freezing point $=3.7681 \mathrm{kj} / \mathrm{kgk}$

Cp below freezing point $=1.92593 \mathrm{kj} / \mathrm{kgk}$

Latent heat $(\mathrm{L})=290.75 \mathrm{kj} / \mathrm{kgk}$

Maximum product load $\left(\mathrm{W}_{\max }\right)=$ Maximum volume occupied $\mathrm{X}$ density of the product

Maximum Volume $=$ Volume of freeze - Volume of compressor compartment

$=(70 \times 60 \times 50)-(25 \times 25 \times 50)$

$=210,000-31,250$

$=178,750 \mathrm{~cm}^{3}$

$=(178,750) /(100)^{3}$

$=0.178750 \mathrm{~m}^{3}$

$\mathrm{W}_{\max }=0.17875 \times 1,060 \times 0.4$

$=75.79 \mathrm{~kg}$

$=76 \mathrm{~kg}$

The 0.4 has been used to multiply, because the compartment that is to be cooled is $40 \%$ of the volume of the freeze.

Product Load

Product load is given as the sum of : heat given off by the product in cooling from entering temperature, heat given off by the product in freezing, that is latent heat of fusion, and heat given off by product in cooling from its freezing temperature to the final temperature.

$\mathrm{Q}=\mathrm{q}_{1}+\mathrm{q}_{2}+\mathrm{q}_{3}$

$=\operatorname{MCp}\left(\mathrm{T}_{2}-\mathrm{T}_{1}\right)+\mathrm{ML}+\mathrm{MCp}\left(\mathrm{T}_{2}-\mathrm{T}_{1}\right)$

$=(76 \times 3.76812(30--2.2))+(76 \times 290.75)+(76 \times 1.92593 \times(-2.2--20))$

$=(76 \times 3.76812 \times 32.2)+(76 \times 290.75)+(76 \times 1.92593 \times 17.8)$

$=9221.34+22097+2605.40$

$=33,923.74 \mathrm{kj}$

Using a freezing point of 13 hours for the whole content of the compartment to freeze.

$=\mathrm{Q} /(13 \times 60 \times 60)$

$=33923.74 /(13 \times 60 \times 60)$

$=0.7249 \mathrm{kw}$

\begin{tabular}{|lll|} 
Temp $\left({ }^{0} \mathbf{F}\right)$ & Liquid & Saturated vapour \\
\hline $\mathbf{0}$ & 103.8 & 275.3 \\
\hline $\mathbf{2 0}$ & 114.0 & 281.6 \\
\hline $\mathbf{9 5}$ & 153.1 & 305.0 \\
\hline
\end{tabular}

Table 2 : Extract of saturated butane enthalpies in Btu/lb and Fahrenheit

Source : Thermodynamic Properties of Saturated butane, www.elyenergy.com 


\begin{tabular}{|lll|}
\hline Temp $\left({ }^{\circ} \mathrm{C}\right)$ & Liquid & Saturated Vapour \\
\hline $\mathbf{- 2 0}$ & 241.4 & 640.3 \\
\hline $\mathbf{- 7 . 5}$ & 265.2 & 655.0 \\
\hline $\mathbf{3 9 . 4}$ & 356.1 & 709.4 \\
\hline
\end{tabular}

Table 3 : Converted Values of Extract of saturated butane enthalpies in degree Celsius and $\mathrm{KJ} / \mathrm{Kg}$

Enthalpies of butane from saturated table of butane for the design:

$\mathrm{h}_{1}=241.4 \mathrm{kj} / \mathrm{kg}, \mathrm{h}_{2}=640.3 \mathrm{kj} / \mathrm{kg}, \mathrm{h}_{3}=709.4 \mathrm{kj} / \mathrm{kg}, \mathrm{h}_{4}=356.1 \mathrm{kj} / \mathrm{kg}$

Refrigerating Effect

Refrigerating effect $=\mathrm{h}_{2}-\mathrm{h}_{1}$

$=640.3-241.4$

$=398.9 \mathrm{kj} / \mathrm{kg}$

Mass Flow Rate (m)

The mass flow rate of refrigerant is related by the equation

$\mathrm{m}\left(\mathrm{h}_{2}-\mathrm{h}_{1}\right)=$ total cooling load

$\mathrm{m}=$ Total cooling load $/\left(\mathrm{h}_{2}-\mathrm{h}_{1}\right)$

$=0.7249 /(640.3-241.4)$

$=0.7249 / 398.9$

$=0.0018172 \mathrm{~kg} / \mathrm{s}$

Compressor Power $(\mathrm{Pc}) \quad=\mathrm{m}\left(\mathrm{h}_{3}-\mathrm{h}_{2}\right)$

$=0.0018172(709.4-604.3)$

$=0.0018172 \times 105.1$ $=0.19098772 \mathrm{kw}$

$1 \mathrm{kw}=4 / 3 \mathrm{Hp}$

$0.191 \mathrm{kw}=$ ?

$$
\begin{aligned}
? & =4 / 3 \times 0.191 \\
& =0.255 \mathrm{Hp}
\end{aligned}
$$

For safety, a compressor of $1 / 2 \mathrm{Hp}$ is selected.

Coefficient of Performance (COP)

$\mathrm{COP}=\left(\mathrm{h}_{2}-\mathrm{h}_{1}\right) /\left(\mathrm{h}_{3}-\mathrm{h}_{2}\right)$

$$
\begin{aligned}
& =(640.3-241.4) /(709.4-640.3) \\
& =398.9 / 69.1 \\
& =5.773
\end{aligned}
$$

Heat Rejection at the Condenser (Qr)

The heat rejected at the condenser $\mathrm{Qr}=\mathrm{m}\left(\mathrm{h}_{3}-\mathrm{h}_{4}\right)$

$=0.0018172(709.4-356.1)$

$=0.0018172 \times 353.3$

$=0.642 \mathrm{kw}$

\section{CONCLUSION AND RECOMMENDATION}

From the analysis, it is evident that butane can be used as a refrigerant with excellent thermodynamic properties. The utilization of the butane-gas, will help control gas flaring from refineries and sites of drilling crude oil in Nigeria and other Countries. Again, an environmentally friendly deep freeze is obtained for the tropics. The demand for refrigeration services are very essential for industrialization .

\section{REFERENCES}

[1] ASHRAE, 1997.ANSI/ASHRAE Standard 34-1997. Designation and Safety Classification of Refrigerants Atlanta, Ga: ASHRAE www.ASHRAE.org

[2] McQuay International, (2002), Application Guide AG 31- 007. www.mcquay.com 8Pp Retrieved on $25^{\text {th }}$ September, 2011.

[3] Pauken,M, (May, 1999). Sleeping Soundly on Summer Nights. ASHRAE Journal

[4] Rogers, G.F.C and Mayhew, Y.R (1992), Engineering Thermodynamics $4^{\text {th }}$ ed., ELBS Pp 276

[5] Thermodynamic Properties of Saturated Butane; www.elyenergy.com1Pp Retrieved on 14 ${ }^{\mathrm{TH}}$ August, 2012.

[6] Thevenot, R.(1979). A History of Refrigeration Throughout the World. International Institute of Refrigeration (IIR). www.iifiir.org .

[7] Intergovernmental Panel on Climate Change (1995) Report on HFCs Table 2.9: CFCs and HCFCs Table. www.ipcc.ch

[8] Ozone Secretariat UNEP (1996); www.un.org . 